\title{
The Evolution of the Crime-Terror Nexus in Europe
}

Noemi Maria Rocca

PhD candidate in International Relations - International Politics and Conflict Resolution, Faculdade de Economia, Universidade de Coimbra.

\begin{abstract}
Empirical evidence confirms that in Europe there are growing links between criminal organizations (OCs) and terrorist groups (GTs) - known as the "crime-terror nexus". After the end of the Cold War and, particularly, since global financial operations came under greater control, the financing of illicit and criminal actions has consequently been conditioned. This resulted in greater proximity and cooperation between OCs and WGs not only in fragile states or undemocratic regimes, but in the western democracies themselves. The article also analyzes the content of the judicial sentences on cooperation and collusions between terrorist groups and criminal organizations.
\end{abstract}

Keywords: crime-terror nexus; terrorist groups; jihadists; criminal organizations; ISIS; mafias.

\begin{abstract}
Resumo
A Evolução do Nexo Crime-Terror na Europa

Evidências empíricas confirmam que na Europa estão a crescer as ligações entre organizações criminosas (OCs) e grupos terroristas (GTs) - denominado "nexo crime-terror". Após o fim da Guerra Fria e, particularmente, desde que as operações financeiras mundiais passaram a ser objeto de um maior controlo, o financiamento de ações ilícitas e criminosas passou consequentemente a ser condicionado. Deste facto resultou uma maior aproximação e cooperação entre as OCs e os GTs não apenas em Estados frágeis ou regimes não democráticos, mas nas próprias democracias ocidentais. O artigo analisa ainda o conteúdo das sentenças judiciais sobre a cooperação e colusões entre grupos terroristas e organizações criminosas.
\end{abstract}

Palavras-chave: nexo crime-terror; grupos terroristas; jihadistas; organizações criminosas; ISIS; máfias. 


\section{Introduction}

The United Nations have recognized the existence of interlinkages between COs and TOs (the so-called "crime-terror" nexus) through many UN Security Council Resolutions, the last one adopted on 19 July 2019. That same year, the UN General Assembly special session on the world drug problem focused on the challenges posed by the link between drug trafficking and terrorism, and encouraged all forms of cooperation between state members to combat it. The United Nations Organization for Combating Drugs (UNODC) in its 2017 World Drug Report approaches the complex interlinkages existing between terrorism and organized crime not only in weak/failed states and corrupted regimes, but in Western countries also. However, it states that "evidence on the organized crime-terrorism nexus remains patchy at best. Moreover, these links are not static. Relations between organized crime and terrorist groups are always evolving, much like drug markets themselves" (UNODC, 2017). It admits also that "[m]ost information on terrorism is collected by intelligence agencies and is classified, meaning that researchers have to rely on media reports and studies issued by non-governmental organizations and think tanks" (UNODC, 2017, p. 11). As a consequence, scholars find many obstacles in getting the real dimensions of the TOC-TGs nexus, tend to focus their attention on the most studied cases - i.e., Latin American and Central Asian states - and to under-estimate it in other contexts ${ }^{1}$. The mentioned UNODC report states that, let apart Latin America, Central and South-East Asia, and Africa, "[e]lsewhere in the world, the evidence supporting links between terrorist, insurgent and nonState armed groups and the illicit drug trade is less rigorous" (UNODC, 2017, quot., p. 37). Yet, for example, "[a]s early as 1993, French authorities uncovered evidence that illegal drug sales in Muslim slum areas were under the direction of Afghan War veterans with ties to Algerian terrorist groups" (Roth, 2010, pp 45-44). In July 2017, the Organization for Security and Co-operation in Europe (OSCE) organized a Conference on the Nexus between Illicit Drugs, Organized Crime and Terrorism. Peter Gridling, Director of the Austrian Federal Agency for State Protection and Counter Terrorism, in his opening address said that "[ $t$ ]he link between trafficking in drugs, organized crime and terrorism might not be a new phenomenon, but it has reached an entirely new dimension through the availability of modern technology and the increasing interconnectedness of our world". Such a gathering of experts, judicial authorities, and law enforcement agents involved in fighting

1 Basra, Neumann and Brunner noted in 2016 that "[w]hile the merging between criminal and terrorist milieus in Europe is real, few scholars have - so far - show any interest in studying $\mathrm{it}^{\prime \prime}$ and that, as a consequence, "the convergence of criminals and jihadists in Europe has gone largely un-noticed" (p. 13). 
the nexus produced a valuable confrontation concerning not only the proofs of its existence in Europe, but also the best practices adopted to counter it. In particular, during his speech ${ }^{2}$, the Italian representative, prosecutor Nicola Gratteri, focused on the political consequences of the TCOs-TGs interplay in Western countries and reportedly presented some evidences about its existence in Italy. This article, after a preliminary assessment of the relevant literature, will exposes the main cases of the TGs and COS interplay discovered in Italy in the last five years.

\section{The Literature on the Crime-Terror Nexus}

In the past, TCOs and TGs were considered to be distinct entities without overlapping features because TCOs are only motivated by financial gains while TGs are only ideologically motivated. Yet, contrary to this belief, Dishman (2001 and 2005) and Makarenko (2004) developed the idea of a spectrum, a continuum along which exists a wide range of possible interplay between the two actors, even if their motivations remain different. In other words, although pushed by dissimilar motives, TCOs and TGs can develop alliances, convergences, and operational collaborations. In addition, for Makarenko, both COs and TGs can evolve into hybrid organizations - partially criminal, partially terroristic entities - because they can learn from each other and change, by adapting themselves to external difficult conditions. According to Shelley, the forms the interplay between TCOs and TGs takes depend on the external context: in war regions, for example, the relationship between them tends to be deeper and more stable over time. In certain contexts, in particular, i.e. failed / weak states, and undemocratic or corrupted regimes, there is a third actor at play in the nexus: the state itself which can be entangled with TGs and COs through corruption and/or complicity (Shelley, 2005) ${ }^{3}$. Moreover, according to Shilley and Picarelli, the dichotomy "methods vs. motives" in analyzing TCOs and TGs is not always true. In fact, there can be cases in which COs and TGs have in common not only methods but also motives, the latter usually being financial ones (Shelley and Picarelli, 2005). They describe the TGs-COs nexus as a process which grows through three main stages. At the first one, they act as distinct entities, buying and selling services from each other. They arrive also at using each other's methods, in a kind of "activity appropriation" process. Then, at the second step, TGs and COs, having recognized that both of them have similar methods and objectives, start to work closely. Finally, at the third stage, the two actors use overlapping

2 The documents of the OSCE-wide Conference are available online at: https:/ / polis.osce.org/ events/oscedc2017

3 See also Shelley (2014). 
networks and cooperate in various illicit operation. Although the latter is described as an unlikely situation, it is precisely the stage in which evidences presented in this article belong to. For Wang (2010), "some terrorists have actually developed into self-sufficient organizations with "in-house" criminal capabilities through the process of self-transformation". Other authors have studied TGs from the perspective of their financial sources and their findings throw a new light on the TGs-COs nexus. Freeman (2011) classified the jihadist terrorist groups' funding sources in four basic groups: legal activities, states' sponsorships, popular support, and illicit activities. In the latter group, the main sources are: document fraud; abuse of registered charities; extortion of taxes and tariffs, blockading of trade routes, and smuggling of archeological artifacts; the diversion and smuggling of natural resources as diamonds, opium and oil; trade in manufactured commodities (medicines, drugs, cigarettes) and, increasingly, human trafficking. By showing how the main financial sources have increasingly became related to criminal operations, he concludes that TGs have moved closer to COs. Windle (2018) too, by applying the Makarenko's spectrum/continuum model of the COs-TGs interplay, explores the most used sources of financing and gets a similar conclusion. Thachuk and Lal (2018), through a detailed analysis of TGs financial means, conclude that modern terrorist groups have completely evolved into criminal enterprises. According to Loretta Napoleoni $(2004 ; 2005 ; 2007)$ who has been monitoring for years the economy of TGs by using a Marxian political economy framework, the Islamic State in Iraq and the Levant (ISIL) is the only TG which has been able to successfully privatize the terrorist business. This privatization freed it from depending on states' sponsorship and war economy (Napoleoni, 2014). Moreover, through extensive empirical researches and first-hand interviews, she proves how kidnapping and human trafficking have turned to be not only ISIL's main sources of funding but also its core business and mission, leaving religious ideology's objectives well apart (Napoleoni, 2017)4. According to Basra, Neumann and Brunner (2016, quot.), for what concerns specifically Jihadist terrorist groups, their interplay with COs has evolved into a "new" type of nexus, where both methods and objectives are criminal. For him, this evolution happened because the majority of Jihadist terrorists have a criminal past and prisons represent an important hub for Jihadists' radicalization and recruitment ${ }^{5}$. Recently, Makarenko (European Parliament, 2012) ${ }^{6}$ produced a study for the European Parliament in which she analyzed and categorized the forms the TGs-COs

4 Similar conclusions are those reached by investigative journalist Rukmini Callimachi (2014).

5 The literature on the role of prisons in the process of terrorists' radicalization is extensive. See for example Silke (2014).

6 See also Makarenko and Mesquita (2014). 
nexus has taken in Europe since the end of Second World War. Such a report is, so far, the most complete and detailed empirical analysis of the nexus in Europe. Her findings confirm the region-specific feature of the nexus, whilst at the same time they prove that TGs and COs have developed different forms of cooperation not only in failed/weak states, unstable regions, and corrupted regimes, but also in Western modern democracies. The Italian case in particular is deeply examined, even though the study covers events happened only up to 2014. Since then, Italian law enforcement agencies and magistrates unveiled evidences of a TGs-COs interplay similar to that represented by Shelley and Picarelly's third and final stage of the nexus and which is worth of being analyzed.

\section{The Italian Case}

At the end of the XIX century, Italy was the birth-place of various mafias. In addition, during the Cold War, it was a theatre of national extremist left- and rightwing TGs' attacks. It was also a shrine for foreign TGs' activities and displacements, and, more importantly, for COs and TGs interplay ${ }^{7}$. Nowadays, Italy - which possesses almost eight thousand kilometers of costs and is geographically very close to Balkan countries (to East), and African continent (to South) - represents an important hub for various kind of illegal trafficking (De Stefano, Sartori and Trento, 2019). In particular, its ports are key-points of COs' controlled drug trade coming through the so-called "Eastern route" - from Afghanistan through the Balkan peninsula - as well as the "Southern" one departing from Latin and Central America through Africa, and then to Europe. Depending on the controlled territory, Italian COs are called "Cosa Nostra" (in Sicily region), "Camorra" (in Campania), "Ndrangheta" (in Calabria) and "Sacra Corona Unita" (in Puglia). They play a central role in all sorts of international illicit trade, thanks not only to their own presence in foreign countries (as in Germany, Guinea Bissau, Spain, Canada, and the U.S., just to mention a few) but also to their alliances and agreements with other foreign COs, as the Albanian and Nigerian mafias, for example. The Italian security community has a long-lasting experience in dealing with $\mathrm{COs}^{\prime}$ and TGs' activities, practices,

7 See, among others, Palermo (1996 and 2019), both of them written by the former prosecutor Carlo Palermo who, during the Seventies and the Eighties, was in charge of important enquires about the connections between terrorism, illicit arms trade and local and foreign mafias. See also Alemi (2019), written by the former prosecutor Carlo Alemi who was in charge of the judicial procedure about Ciro Cirillo's - a politician belonging to Christian Democracy, then the first political party in Italy - kidnapping by the TG Red Brigades.

8 On this topic, in English: Nicaso and Lamothe (1995), Gambetta (1993) and Dickie (2013). In Italian, among many other ones: Gratteri and Nicaso (2019) and Giannulli (2019). 
and evolving interconnections. This experience has led to operational and judicial effective solutions for countering COs-TGs connections. Crime-terror nexus leading specialist Louise Shelley often acknowledges the Italian case's specificity and the competence Italian judiciary and law enforcement agencies have developed. Recently, after the 2014-2016 ISIL attacks in Europe, during a testimony at the U.S. Homeland Security's Subcommittee on Counterterrorism and Intelligence, she stressed the fact that, differently from the rest of the European security community - where people in policy positions fail to appreciate the last evolution of the crimeterror nexus - Italians are aware of it because they "have observed these links between crime and terrorism for over three decades" (Shelley, 2016). It is a documented fact that, from the beginning of the Cold War on, US intelligence has been carefully monitoring the evolution of the criminal and terrorist environments in Italy in order to protect American military bases and personnel on Italian soil. In April 1988, a terrorist attack undertaken in Naples against the "US Organization" - a circle of U.S. Navy VI Fleet personnel in the downtown - by the Japanese Red Army (JRA) TG killed 5 people ${ }^{9}$. As a consequence of this event and in preparation for the 1994 G7 summit to be hold in Naples, both Italian and U.S. intelligence dug deeply into Naples' underground environment controlled by the Camorra. One of the results was the discovery of a deep network of connections between some Camorra people and Algerian terrorist cells (De Simone, 2015). The American intelligence agencies' interest for the crime-terror nexus' existence and implications on Italian territory didn't vanish along the years. In fact, a 2005 leaked cable of the US Embassy in Rome made reference to an U.S. Federal Bureau of Investigation's intelligence report asserting the existence in Italy of the nexus between COs and radical Islamist groups ${ }^{10}$. In particular, the cable underlined the possibility Italian mafias could supply TGs financial means and logistical support through the routes they had already developed for arms, drugs and humans trafficking ${ }^{11}$. Such a

9 Between them, a US Navy officer and 3 sailors. See Farrel (1990, pp. 209-210). The year before, in Rome, British and US Embassies also were targeted by JRA's missiles attacks (Ibidem, p. 207).

10 Wikileaks, Public Library of US Diplomacy Website, (2008). US Consulate in Naples. Organized Crime III: Confronting Organized Crime in Southern Italy. The cable quoted the report by writing also that "In a public statement given on April 19, 2004, Italy's national anti-Mafia prosecutor, Pierluigi Vigna, indicated a link between Islamic militant groups and the Camorra, stating that evidence existed implicating the Camorra in an exchange of weapons for drugs with Islamic terrorist groups".

11 In those same years, which represented a particular historical, and judiciary context for Italy, a local mafia - reportedly Cosa Nostra, the Sicilian mafia - changed its usual criminal behavior and used terroristic methods for achieving its objectives. Yet, it was not fully understood whether they borrowed just the method from TGs or there was a cooperation between them. See Giannantoni and Volterra (2014). For a summary in English of those events, see Roth (2010, quot., p. 49). 
scenario is precisely what, in these last years, Italian prosecutors have hypothesized and whose evidences have in some cases been found by investigators. In fact, already in 2004, prosecutor Pierluigi Vigna, at that time Italian Agency for Countering Mafia's (DNA's) ${ }^{12}$ head, said that there were sufficient evidences proving arms-for-drug exchanges between the Camorra and some TGs (Radio Radicale, 2004). More recently, in 2015, former prosecutor and DNA's head - and at that time President of the Italian Senate - Aldo Grasso, admitted that the TGsCOs interplay had planted deep roots in Italy (Grasso, 2015). Another former DNAA's head, prosecutor Vincenzo Macrì, reportedly said that ISIL terrorists hadn't attacked Italian sites because they needed Italian territory for their trafficking (Oliva, 2017) ${ }^{13}$. The 2016 DNAA's Final Report stated that: "[t]he evolution of international terrorism and the enquires done so far about the criminal activities of the Islamic State and its affiliates (or aspirant "martyrs") in our country, confirm the interplay between criminal organizations like mafias and international terrorism. Actually, a total interpenetration more than a simple interplay"14. On February 2019, Prosecutor Nicola Gratteri reportedly claimed that "there exist a super-national terroristic agency that relates directly with all the different mafias"15. As a proof of that, he quoted the case of a pusher in Vibo Valentia - a small town in the Calabria region, a territory under the control of the 'Ndrangheta - who didn't pay a drug consignment to Colombian cartels and was intercepted by ETA Spanish terrorists. He also added that ports in particular are the spaces where COs' and TGs' activities converge because it is extremely difficult to totally control them given their huge extension, in Italy as elsewhere ${ }^{16}$. Then, in his opinion, intelligence activity is crucial in fighting the nexus (Nuova Cosenza, 2016). Concerning the last five years, the number of evidences supporting

12 Direzione Nazionale Antimafia (DNA) - National Agency for Countering Mafia. From 2015 on, Direzione Nazionale Antimafia e Antiterrorismo (DNAA) - National Agency for Countering Mafia and Terrorism.

13 In 2018 during a criminal proceeding, a similar opinion was expressed by an important 'Nadrangheta boss who reportedly said that thanks to Sicilian mafia Italy has not been a target for Al-Qaeda's earlier and, later, ISIS' terrorist attacks. See Bongiovanni (2015).

14 Direzione Nazionale Antimafia e Antiterrorismo (2016). Translated by the author.

15 The idea of a super-national entity managing various terrorist groups as well as their interplay with COs is not new in the post-Second World War Italian judiciary experience. During the so-called "plumb-years" (the 70s), which experienced extreme right- and extreme left- terrorist attacks and massacres, various enquires made by many prosecutors discovered proofs of the existence of a Paris-based, cultural center connected to terrorists belonging to different countries and TGs. See Priore (2018), by former prosecutor Rosario Priore.

16 Ports are acknowledged by practitioners and intelligence as being the most vulnerable and crucial part of Italian territory. See Vidino (2016). 
an effective interplay between Italian COs and international TGs, in particular Al-Qaeda and ISIL, is growing. The most important one - because it is a judicial hypothesis consolidated by a final, third grade sentence - is the discovery of the support given by Italian COs to the bombs attack at Madrid's Atocha railway station in 2003, which was demonstrated as financed by drug trade controlled by the 'Ndrangheta in Southern Italy ${ }^{17}$. Other proofs consist of ongoing police investigations, which discovered Libyan oil smuggling by a long-lasting collaboration between the Cosa Nostra mafia and ISIL militias in Libya (Slav, 2017); enquires about Jihadists and COs cooperation in migrant and cigarettes trafficking (Report Difesa, (2018); a first-grade guilty sentence for Nabil Benamir, a radicalized Moroccan citizen living in Italy who, once in prison for charges of terrorism, asked the "Sacra Corona Unita" mafia a supply of Kalashnikov, detonators and explosive T4 for an attack to be carried out in Italy (Grasso and Indice, 2019); discoveries of Camorra people supplying false documents to Jihadists (Il Tempo.it, 2015); the arrest of an Iraqi citizen - holding an international arrest warrant issued in Switzerland for fraud and illegal arms' possession - on charges of having negotiated with the Camorra mafia about arms and false documents trafficking (Nadeau, 2016). In addition to such official operations, investigative journalist Domenico Quirico has discovered the existence of artifacts' illicit trade and arts-for-guns exchanges which had been run, reportedly, in partnership with some Italian mafias - 'Ndrangheta and Camorra -, ISIL terrorists, the Russian mafia and some Chinese COs (Quirico, 2016). The logistic center for the delivery and the commerce was found to be Gioia Tauro, a port in Calabria region of strategic importance for the North African and Middle East routes ${ }^{18}$, reportedly under the full control of the 'Ndrangheta mafia for its benefit and that of the Albanian and Montenegro mafias too. TGs' finance expert Loretta Napoleoni

17 See the interview to the former Italian National Prosecutor, DNAA's Head Franco Roberti, in Boccolini and Postiglione (2017, pp. 31-32 and 49).

18 "Located in the heart of the Mediterranean Sea, a meeting point between the East-West shipping routes and the trans-European corridor 1 Helsinki - La Valletta, Gioia Tauro is the largest terminal for transshipment in Italy and one of the most important hubs of the container traffic in the basin of the Mediterranean Sea. Overlooking the lower part of the Tyrrhenian Sea [...] it is in a barycentric position with respect to the corridors of intercontinental routes that ply the Mediterranean basin and in the middle position along the axis of Suez - Gibraltar. The port infrastructure, classified as 2nd Category - 1st class - is of international importance and it is endowed with infrastructure and means to accommodate trans-oceanic vessels in transit in the Mediterranean Sea and capable of dealing with any commercial category". Source: Autorità Portuale di Gioia Tauro. [online] Available at: http://www.portodigioiatauro.it/porto-gioia-tauro/mission-values / [Accessed 12 November 2019]. 
has been investigating for a long time the management of human trafficking from West Africa to Italy through Libyan ports. She demonstrated that it has been carried out by Al-Qaeda and, increasingly, ISIL, with the support of local mafias in Italian ports (Napoleoni, 2017, quot.). Two recent discoveries in Italian ports of an illicit trade of chemical precursors ${ }^{19}$ make further questions arise about the level of cooperation/ collusion between TGs, in particular ISIL, and local mafias. On November 21, 2017, the Italian Finance Police - during an inspection reportedly undertaken with the cooperation of the American Antidrug Agency (Guardia di Finanza, 2017) - discovered in an Indian cargo boat, arrived at the Genova harbor from Sri Lanka, 7.5 tons of Captagon pills, whose commercial value was estimated in $€ 75$ million. The boat was headed to the port of Tobruk, in Libya and the cargo belonged to a Dubai company. According to the prosecutor in charge of the judicial inquiry, Italian ports are at the center of this illegal traffic. From Genova, the pills were supposed to go to Libya and from there to Egypt. According to both Italian and US investigators, the traffic would be managed by the same criminal cartel which finances Jihadist groups and operates along the same routes of the human-traffickers (Serafini, 2017). Italian ports are crucial for such a trade because Genova is one of the only two European ports from which cargos can be headed to Libya ${ }^{20}$. In November 2017, a second, huge shipment of chemical precursors this time Tramadol, an opioid painkiller - was found by the Counter-Terrorism section of the DNAA agency at the abovementioned port of Gioia Tauro. This time, the estimated total value was $€ 70$ million. According to American sources of intelligence, "the narcotic drug was intended for ISIS terrorists or to finance their activities" (Martinelli, 2017). In this case, the drugs were coming from India and headed again to Libya. Italian and US investigators reportedly stated that the Tramadol illicit trade is managed directly by ISIL for financing its activities

19 In their last 2019 reports, both the United Nations Office for Drugs and Crime (UNODC) and the European Monitoring Centre for Drugs and Drugs Addiction (EMCDDA) claimed that the use of amphetamines is growing rapidly in the world, particularly in Africa, and especially in the Eastern part of the continent. UNODC (2017), quot. In its 2017 Report, Global Initiative - a private-based network of law enforcement officials of different countries - claimed that "the growth of the illicit economy around the drug Captagon - a global illicit industry - worth an estimated US\$ 1 billion a year. Captagon is an amphetamine and popular party pill widely used throughout the Gulf countries. Profit margins of Captagon are astonishingly high: a single pill can be produced for a few cents with easy to access precursor chemicals, but currently retails at up to US\$20 in the Gulf". See Global Initiative (2017).

20 When the final destination is Syria, the transit port is Pireo, where in 2016 and 2019 law enforcement agents discovered 26 millions of pills hidden in an Indian cargo boat. See Soutiliotis (2019). 
worldwide, in particular in Libya, in Syria and in Iraq (Next Quotidiano, 2019). To conclude, all these recent findings seem to confirm the forecast by the current DNAA's head, Federico Cafiero de Raho, formulated already in 2015. It is worth quoting him entirely:

“The 'Ndrangheta needs arms and drug; terrorists, for operating on the territory, need secret and safe logistic bases, and need also places and people able to offer hospitality and cover. 'Ndrangheta doesn't lack of such a feature: it owns a widespread control of the territory and is a transnational organization, it engages with actors in the Middle and the Far East [...]. All these elements lead to think that if ISIS would look for solid points of support, it could find them here, in Calabria" (Loira, 2015) ${ }^{21}$.

In other words, there are evidences supporting the hypothesis that, in Italy, the crime-terror nexus has evolved in structured, stable activities performed by TGs and COs along a kind of chain of production and according to a definite division of labor. Local COs allow the use of their illicit traffic routes by international TGs, reportedly ISIL; in addition, they supply them with documents, safe logistic bases and reliable networks for moving and hiding people. What, so far, has been proved as furnished by ISIL consists in incoming fluxes of migrants, artifacts, and oil, all of them to be traded in Europe by COs. Further research is needed for understanding by which one of the two actors other commodities - in particular, drugs and arms - have usually been made available.

\section{Conclusions}

The crime-terror nexus theoretical frame is an effective tool for analyzing the complex net of linkages existing between TGs and COs not only in unstable or undemocratic regimes but also in Western democratic states. Because of Italy's vulnerability - due to its huge costal perimeter and to the existence of organized local mafias in control of important parts of its territory - its case shows how deeply the interplay between TGs and OCs has been developing in the last years: "[a] total interpenetration more than a simple interplay" ${ }^{22}$. Among others, the connections between COs and TGs for the illicit trade of chemical precursors - a drug-terror sub-nexus - are particularly interesting. Usually, drug trade has been undertaken by terrorist groups for financing their ideological core mission directly - with criminal cartels' allowance - or indirectly - with such cartels' operational support. In the case of Captagon's and Tramadol's illicit trade through Mediterranean ports, it is not yet clear in what form, whether directly by TGs or indirectly with the support of COs' networks, it

21 Translated by the author.

22 See Priore (2018), by former prosecutor Rosario Priore. 
has been carried out so far. However, the fact that such huge volumes of drugs could have reached terminals, like the Gioia Tauro harbor - which is under control of the 'Ndrangheta mafia specialized in illicit drug trade - supports the hypothesis that the TG benefitting of this trade, reportedly ISIL, is deeply interconnected with those COs in control of the European channels of drug distribution. From a theoretical point of view, this article proves that what was predicted as possible but unlikely (Shelley and Picarelli, 2005), i.e., the use by both TGs and COs of overlapping networks and their cooperation in illicit enterprises, has turned out to be common, at least in the case analyzed. Secondly, it supports the assumption according to which "terrorist and criminals often use the same methods, most often for divergent motives - but not always" ${ }^{23}$. Concerning in particular ISIL, the search of funds appears to be the basic motive which pushes its actions, confirming what experts as Thachuk and $\mathrm{Lal}^{24}$, and Napoleoni ${ }^{25}$ had already affirmed, i.e. that ISIL has turned into a criminal organization focused on profits. Finally, that the same important policy recommendations arising from Shelley and Picarelli's analyses still hold valid, i.e., "to incorporate crime analysis in the work of intelligence analysts and law enforcement officers addressing terrorism" ${ }^{26}$. In fact, the Italian case shows that coordination between counter-terrorist law enforcement agencies, intelligence, and finance police in charge of the economic control of the territory can be effective in detecting and countering the forms the COs-TGs nexus has developed in the more recent years.

\section{Bibliography}

Alemi, C. 2019. Il caso Cirillo. La trattativa Stato-Brigate Rosse-Mafia. Napoli: Tullio Pironti.

Autorità Portuale di Gioia Tauro. Porto di Gioia Tauro. [Online] Available at: http:/ /www. portodigioiatauro.it/porto-gioia-tauro/mission-values/ [Accessed 12 November 2019].

Basra, R., Neumann, P. and Brunner, C., 2016. Criminal Pasts, Terrorist Futures: European Jihadists and the New Crime-Terror Nexus. London: The International Centre for the Study of Radicalisation and Political Violence.

Boccolini, M. and Postiglione, A., 2017. Sahara, deserto di mafie e Jihad. Roma: Castelvecchi.

Bongiovanni, G., 2015. Le rivelazioni di Graviano: "Attentati evitati grazie a Cosa Nostra". Antimafiaduemila [online], 13 April. Available at: http://www.antimafiaduemila.com/ rubriche / giorgio-bongiovanni / 69875-le-rivelazioni-di-graviano-attentati-islamici-evitati-grazie-a-cosa-nostra.html

23 Ibidem, pag. 53.

24 Thachuk and Lal, 2018, quot.

25 Napoleoni, L., 2017, quot.

26 Shelley, L. I., Picarelli, J. T., et al., 2005, quot. pp. 53-54. 
Callimachi, R., 2014. Ransoming Citizens. Europe becomes Al-Qaeda patron. The New York Times [online], July 29. Available at: https://www.nytimes.com/2014/07/30/world/ africa/ransoming-citizens-europe-becomes-al-qaedas-patron.html?_r=0 [Accessed 10 December 2019].

De Simone, A., 2015. Terrorists' papers forged in Naples. Corriere della Sera [online], January 19. Available at: https://www.corriere.it/english/15_gennaio_19/terrorists-papers-forged-naples-01aac748-9fc8-11e4-84eb-449217828c75.shtml. [Accessed 1 December 2019].

De Stefano, C., Sartori, E. and Trento, I. S., eds., 2019.Terrorismo, Criminalità, Contrabbando. Gli affari dei Jihadisti tra Medio Oriente, Africa ed Europa. Napoli: Rubbettino.

Direzione Nazionale Antimafia e Antiterrorismo (DNAA), 2016. Relazione annuale sulle attività svolte dal Procuratore nazionale antimafia e dalla Direzione nazionale antimafia nonché sulle dinamiche e strategie della criminalità organizzata di tipo mafioso nel periodo $1 .^{\circ}$ luglio 2014-30 giugno 2015. [online] Available at: https: / / www.publicpolicy.it/wp-content/ uploads / 2016/ 03 / Relazione-Franco-Roberti-Dna.pdf [Accessed 12 November 2019].

Dishman, C., 2005. The Leaderless Nexus. Studies in Conflict \& Terrorism, 28(3), pp. 237-252.

Dishman, C., 2001. Terrorism, crime, and transformation. Studies in Conflict \& Terrorism, 24(1), pp. 43-58.

European Monitoring Centre for Drugs and Drugs Addiction (EMCDDA), 2019. "Captagon: understanding today illicit traffic". [Online] Available at: http: / /www.emcdda.europa.eu/ publications/emcdda-papers/captagon-understanding-todays-illicit-market_en [Accessed 12 November 2019].

European Parliament, 2012. Europe's Crime-Terror Nexus: Links between Terrorists and Organized Crime Groups in the European Union. [Online] Available at: http: / / www.europarl.europa. eu/document/activities / cont/201211/20121127ATT56707/20 121127ATT56707EN.pdf [Accessed 10 September2019].

Farrel, W.R., 1990. Blood and rage: the story of the Japanese Red Army. Lexington, MA: Lexington Books.

Freeman, M. 2011. Sources of Terrorist Financing: Theory and Typologies. In Freeman, M., ed., Financing Terrorism. Case Studies. Abingdon: Ashgate.

Giannantoni, M. and Volterra, P., 2014. L'operazione criminale che ha terrorizzato l'Italia. La storia segreta della Falange Armata. Milano: Newton Compton.

Global Initiative, 2017. Captured by Captagon? Lebanon's evolving illicit drug economy. [online] May. Available at: https://globalinitiative.net/article_type/publications / [Accessed 7 October 2019]. 
Grasso, M. and Indice, M., 2019, Le motivazioni della condanna a Benamir: "Affiliato dell'ISIS voleva armi". Il Secolo XIX [online], 26 February. Available at: https:/ /www. ilsecoloxix.it/genova/2019/02/26/news / le-motivazioni-della-condanna-a-benamir-affiliato-dell-isis-voleva-armi-1.30323794 [Accessed 12 November 2019].

Grasso, P., 2015, Il rapporto tra traffici illeciti e terrorismo. Speech at the Italian Senate [online], November 16. Available at: http://www.radioradicale.it/scheda/458928/il-rapporto-tra-traffici-illeciti-e-terrorismo [Accessed 10 December 2019].

Guardia di Finanza. Comando Provinciale di Genova, 8 May 2017. Sequestrate oltre 37 tonnellate di droga del combattente. [Online] Available at: http://www.gdf.gov.it/stampa/ ultime-notizie / anno-2017 / maggio / sequestrate-oltre-37-tonnellate-di-droga-del-combattente [Accessed 7 October 2019].

IlTempo.it., 2015. La Camorra fa i documenti all'ISIS. Il Tempo.it [online], January 21. Available at: https: / / www.iltempo.it/ politica / 2015/01/21 / gallery/la-camorra-fa-i-documenti-allisis-965886/ [Accessed 12 November 2019].

Loira, D., 2015. Cafiero de Raho insiste: 'Ndrangheta-ISIS legami concreti: il terrorismo cova in Calabria. StrettoWeb.com [online], 24 February. Available at: http:/ / www.strettoweb. $\mathrm{com} / 2015$ / 02 / reggio-cafiero-de-raho-insiste-ndrangheta-isis-legami-concreti-terrorismo-cova-in-calabria/250329/ [Accessed 7 October 2019].

Makarenko T., 2004. The crime-terror continuum. Tracing the interplay between transnational organized crime and terrorism. Global Crime, 6(1), pp. 129-145.

Makarenko T. and Mesquita, M., 2014. Categorising the crime-terror nexus in the European Union. Global Crime, 15(3-4), pp. 259-274.

Martinelli, A., 2017. What does ISIS “fighter drug" have to do with Italy. La Stampa [online]. Available at: https: / www.lastampa.it/ esteri/la-stampa-in-english/2017/11/03/news/ what-does-isis-fighter-drug-have-to-do-with-italy-1.34378716 [Accessed 1 October 2019].

Nadeau, B. L. 2016. The mafia runs guns for ISIS in Europe. The Daily Beast [online], March 24. Available at: https://www.thedailybeast.com/the-mafia-runs-guns-for-isis-in-europe?ref=scroll [Accessed 12 November 2019].

Napoleoni, L., 2017. Merchants of Men. How Kidnapping, Ransom and Trafficking Fund Terrorism and ISIS. New York: Atlantic Books.

Napoleoni, L., 2014. The Islamist phoenix. The Islamic state and the redrawing of the Middle-East. New York: Seven Stories Press.

Napoleoni, L., 2007. Terrorism financing in Europe, in Giraldom, J. K. and Trinkunas, H. A., eds., Terrorism Financing and State Responses: A Comparative Perspective. Stanford: Stanford University Press.

Napoleoni, L., 2005. Terror Incorporated. Tracing the dollars Behind the Terror Networks. New York: Seven Stories Press. 
Napoleoni, L., 2004. The new economy of terror. How terrorism is financed. Forum on Crime and Society, 4(1/2), pp. 31-49.

Next Quotidiano, 2019. Tramadolo. Cos'è la droga del combattente. [online] 3 November. Available at: https: / / www.nextquotidiano.it/tramadolo-cose-la-droga-del-combattente/ [Accessed 7 October 2019].

Nuova Cosenza, 2016. Gratteri all'Unical: Terrorismo interagisce con le mafie. [online] 19 February Available at: http://www.nuovacosenza.com/cs/19/feb/16/gratteri.html [Accessed 11 September 2019].

Oliva, R. H., 2017. L’Ex procuratore Macrì: “L'ISIS non colpisce l'Italia perché si serve delle nostre mafie. Milano centrale europea della cocaina" Corriere della Sera-Corriere TV [online], 24 September. Available at: https://video.corriere.it/ex-procuratore-antimafia-vincenzo-macri-terroristi-islamici-non-colpiscono-l-italia-perche-hanno-bisogno-traffici-le-mafie / 145b0cac-a0f3-11e7-97ce-75ed55d84d04?refresh_ce-cp [Accessed 10 December 2019].

Organization for Security and Co-operation in Europe (OSCE), 2017. Documents of the "Conference on the nexus between illicit drugs, organized crime and terrorism" held in Wien on July 2017. [Online] Available at: https:/ / polis.osce.org/events/oscedc2017; https: / / polis.osce.org/session-2-illicit-drugs-source-financing-illicit-activities [Accessed 10 December 2019].

Palermo, C., 2019. La Bestia. Dai misteri d'Italia ai poteri massonici che governano le democrazie. Milano: Sperling e Kupfer.

Palermo, C., 1996. Il quarto livello: integralismo islamico, massoneria e mafia. Milano: Editori Riuniti.

Priore, R. and De Prospo, S., 2018. Chi manovrava le Brigate Rosse? Storia e misteri dell'Hyperion di Parigi, scuola di lingue e centrale del terrorismo internazionale. Firenze: Ponte alle Grazie.

Quirico, D., 2016. Arte antica in cambio di armi: affari d'oro in Italia. La Stampa. [online]. Available at: https://www.lastampa.it/esteri/2016/10/16/news/arte-antica-in-cambio-di-armi-affari-d-oro-in-italia-1.34788871 [Accessed 12 November 2019].

Radio Radicale, 2004. "Il coordinamento delle indagini di criminalità organizzata e terrorismo". Presentazione del libro di Giovanni Melillo, Armando Spataro e Piero Luigi Vigna (Ed. Giuffrè), organizzata dall'Istituto Italiano per gli Studi Filosofici, dalla Casa Editrice Giuffrè e dall'Associazione Libera (presso la Sede dell'Istituto Italiano per gli Studi Filosofici, Palazzo Serra di Cassano, via Monte di Dio 14). [online] 11 July. Available at: https:/ / www.radioradicale. it/scheda / 159001/il-coordinamento-delle-indagini-di-criminalita-organizzata-e-terrorismo-presentazione [Accessed 10 December 2019].

Report Difesa, 2018. Guardia di Finanza: Operazione "Scorpion Fish 2". Smantellata organizzazione criminale italo-tunisina. Report Difesa. [online], 10 April. Available at: http:/ / www.reportdifesa.it/guardia-finanza-operazionescorpion-fish-2-smantellata-organizzazione-criminale-italo-tunisina/ [Accessed 12 November 2019]. 
Roth, M. P., 2010. Global Organized Crime: A Reference Handbook. Santa Barbara, CA: ABC Clio.

Serafini, M., 2017. Captagon e Tramadolo: così l'ISIS traffica droga (attraverso l'Italia). Corriere della Sera [online], 3 October. Available at: https://www.corriere.it/ esteri /17_agosto_30/captagon-tramadolo-cosi-isis-traffica-droga-attraverso-italia-e76350e6-8d89-11e7-9464-bd6d9adf1594.shtml [Accessed 7 October 2019].

Shelley, L. I., 2014. Dirty Entanglements. Corruption, Crime, and Terrorism. Cambridge: Cambridge University Press.

Shelley, L. I., 2005. The Unholy Trinity: Transnational Crime, Corruption and Terrorism. Brown Journal of International Affairs, 11(2), pp. 101-111.

Shelley, L. I. and Picarelli, J. T., 2005. Methods and Motives: Exploring Links between Transnational Organized Crime and International Terrorism. Trends in Organized Crime, 9, pp. 52-67. Available at: https: / / link.springer.com/article/10.1007/s12117-005-1024-x

Shelley, L., 2016. "Following the Money: Examining Current Terrorist Financing Trends and the Threat to the Homeland", Testimony at the US Homeland Security's Subcommittee on Counterterrorism and Intelligence, May 12, 2016.

Silke, A., 2014. Terrorists, extremist and prison: An introduction to the critical issues. In: Silke, A, ed., Prisons, Terrorism and Extremism. Critical Issues in Management, Radicalisation and Reform. London and New York: Routledge.

Slav, I., 2017. Italian Police are investigating oil smuggling links between the mafia and ISIS. Business Insider [online], August 2. Available at: https: / / www.businessinsider.com/mafia-isis-oil-smuggling-2017-8?IR=T [Accessed 12 November 2019].

Soutiliotis, Y., 2019. Millions of pills hidden in an Indian cargo boat. Ekathimerini [online], 27 June. Available at: http: / /www.ekathimerini.com/241967/article/ekathimerini/news/ millions-of-captagon-pills-seized-in-piraeus [Accessed 7 October 2019].

Thachuk, L. K. and Lal, R., 2018. An Introduction to Terrorist Criminal Enterprise. In Thachuk, L. K. and Lal, R., eds., Terrorist Criminal Enterprise: Financing Terrorism through Organized Crime. Santa Barbara CA: Praeger Security International, pp. 1-9.

United Nations Office on Drug and Crime (UNODC), 2017. World Drug Report 2017. Booklet no. 5: The drug problem and organized crime, illicit financial flows, corruption and terrorism. [Online] Available at: https://www.un-ilibrary.org/drugs-crime-and-terrorism/worlddrug-report-2017_550b8369-en [Accessed 10 December 2019].

United Nations Security Council, 2019. Threats to international peace and security. July 19. [Online] Available at https:/ / undocs.org/S/RES/2482(2019) [Accessed 10 December 2019].

Vidino, L., ed., 2016. Traffici illeciti e infiltrazioni jihadiste nei porti italiani: verso nuove soluzioni. [Online] Available at: http:/ / italianportsecurity.com/. [Accessed 1 November 2019]. 
Wang, P., 2010. The Crime-Terror Nexus: Transformation, Alliance, Convergence. Asian Social Science, 6, pp. 11-20.

Wikileaks, 2008. Public Library of US Diplomacy. US Consulate in Naples. Organized Crime III: Confronting Organized Crime in Southern Italy. June 6. [online] Available at: https: / / wikileaks.org/plusd/cables/08NAPLES38_a.html [Accessed 1 September 2019].

Windle, J., 2018. Fundraising, Organised Crime and Terrorist Financing. In Silke, A., ed., The Routledge Handbook of Terrorism and Counter-Terrorism. Abingdom: Routledge. 